\title{
Numerical Taxonomy of Psychrotrophic Pseudomonads
}

\author{
By GÖRAN MOLIN* AND ANDERS TERNSTRÖM \\ Swedish Meat Research Institute, P.O. Box 504, S-24400 Kävlinge, Sweden
}

(Received 6 July 1981; revised 6 January 1982)

\begin{abstract}
The taxonomy of 218 psychrotrophic pseudomonad strains ( 200 field strains from meat and 18 type and reference strains) was numerically studied by 174 biochemical and physiological tests. All strains were Gram-negative rods, oxidase positive and motile by means of one or more polar flagella. The strains clustered into 15 groups, of which 9 were regarded as major clusters. The major clusters were designated as Pseudomonas fragi (112 strains), $P$. fluorescens biotype III (7 strains), P. fluorescens biotype I (16 strains), P. aureofaciens/ chlororaphis (3 strains), P. fluorescens biotype II (3 strains), P. putida biotype I (4 strains), Alteromonas putrefaciens (10 strains) and Aeromonas hydrophila biotype I (5 strains). One major cluster, containing 21 strains (cluster 2), was left unassigned. The phenotypic data indicate that this cluster might represent a new species. The $P$. fluorescens/P. putida complex matched closely the descriptions of Stanier et al. (1966), but the two largest clusters (1 and 2) were not in agreement with any species described in the eighth edition of Bergey's Manual of Determinative Bacteriology. Cluster 1 included the type strain (ATCC 4973) of the hitherto incompletely described $P$. fragi. A simplified scheme for the separation between $P$. fragi, $P$. fluorescens, $P$. putida and cluster 2 is presented.
\end{abstract}

\section{INTRODUCTION}

The taxonomy of Pseudomonas is, at present, based primarily on the work of Stanier et al. (1966). This study was later supplemented by Ballard et al. (1968, 1970), Misaghi \& Grogan (1969), Davis et al. (1970), Sands et al. (1970), Ralston et al. (1973), Austin \& Goodfellow (1979), Champion et al. (1980), Palleroni (1980) and Pickett \& Greenwood (1980). Psychrotrophic Pseudomonas strains were only included in four of the above papers, and two of these considered mainly plant pathogenic strains.

In the eighth edition of Bergey's Manual of Determinative Bacteriology (Doudoroff \& Palleroni, 1974) and in the above-mentioned reports only three oxidase-positive psychrotrophic Pseudomonas species are described: P. fluorescens, $P$. putida and $P$. cichorii (phytopathogenic). According to the descriptions, these species would all be able to produce fluorescent pigment, and $90 \%$ or more of the strains have been found to do so (Stanier et al., 1966 and Sands et al., 1970, respectively). Thus, the incapacity to produce fluorescent pigments seems to be an unusual characteristic for described psychrotrophic pseudomonads. However, the microbial spoilage flora of refrigerated meat often consists to a high degree of non-fluorescent pseudomonads (Enfors et al., 1979; Blickstad et al. 1981). These apparently 'atypical' psychrotrophic pseudomonads could be non-fluorescent varieties of $P$. fluorescens and/or $P$. putida. On the other hand, they could constitute one or several homogeneous groups of their own, with phenotypical differences from the fluorescent pseudomonads in addition to their inability to form fluorescent pigment. Davidson et al. (1973) studied 231 psychrotrophic pseudomonads and suggested that 'the majority of commonly occurring pseudomonads on meat and meat products do not conform with the species proposed by Stanier et al. (1966)'. Similar results have been reported by Shaw \& Latty (1981) and, from fish, by Gray \& Stewart (1980). 
The intention of the present study was to characterize psychrotrophic pseudomonads and to analyse their taxonomy in accordance with the principles suggested by Stanier et al. (1966).

\section{METHODS}

Strains. Strains used in the study are listed in Table 1.

Isolation of field strains. Psychrotrophic counts on tryptone glucose extract agar (Oxoid; incubated at $4{ }^{\circ} \mathrm{C}$ for $10 \mathrm{~d}$ in air) were made from meats of different origin. Colonies were randomly picked and screened for oxidase production (Kovacs, 1956), Gram-negative reaction (Bacto Gram stain set; Difco), motility Iphase-contrast microscopy after growth in nutrient broth (NB; Oxoid) for $20 \mathrm{~h}$ at $25^{\circ} \mathrm{C}$ ) and polar flagellation (Mayfield \& Inniss, 1977).

The isolates were picked from meat, representing a contamination level of $10^{2}-10^{9}$ psychrotrophic colony-forming units $\mathrm{cm}^{-2}$. Only one isolate was taken from each piece of meat.

All the isolations were made during a 2 month period. The isolates were grown in NB at $25^{\circ} \mathrm{C}$ for $3 \mathrm{~d}$ (static cultures). The cultures were then stored at $2{ }^{\circ} \mathrm{C}$ and used as stock cultures. All isolates were tested within a 6 month period after the isolation and then, after testing, checked for purity and reaction on the first 10 biochemical tests performed. All the isolates were tested on a particular test at the same time. The type and reference strains were treated in the same way.

\section{Properties examined.}

Including the tests used in the screening procedure, a total of 192 characteristics were studied. Tests were done at $25^{\circ} \mathrm{C}$ and reactions were read after $4 \mathrm{~d}$ unless otherwise stated.

Morphology. Cell shape, cell size (NB for 16-96 h) and colony appearance [nutrient agar (NA) and blood agar for $1-10 \mathrm{~d}]$ were studied.

Pigment production. Pink or yellow pigmentation was noted on nutrient agar after 2 and $7 \mathrm{~d}$. Phenazine pigments were noted on King A medium and fluorescent pigments on King B medium after 1-5 d (King et al., 1954).

Growth at different temperatures. Growth or no growth was recorded in NB incubated at $4{ }^{\circ} \mathrm{C}(10 \mathrm{~d}), 37^{\circ} \mathrm{C}$ (2d) and $42^{\circ} \mathrm{C}(2 \mathrm{~d})$.

Growth at different $\mathrm{NaCl}$ concentrations. Growth or no growth was recorded on NA plates supplemented with $3 \%$ and $6 \%(\mathrm{w} / \mathrm{v}) \mathrm{NaCl}$.

Oxidative and fermentative utilization of glucose. Test tubes with the medium of Hugh \& Leifson (1953) supplemented with agar to a total strength of $1.5 \%$ were incubated aerobically and anaerobically (Gas Pak Anaerobic System, BBL). In the anaerobic incubation $8 \mathrm{ml} 0.1 \%(\mathrm{w} / \mathrm{v})$ bromocresol purple was used as indicator instead of bromothymol blue. The tubes were examined for acid and gas production, as indicated by a change of colour and disruption of the agar, respectively.

Acid production from carbohydrates. The medium of Hugh \& Leifson ( $1.5 \%$ agar, plates) was supplemented with the following sterile filtered carbohydrates (final concentration $1 \%$, w/v); adonitol, amygdalin, L-arabinose, cellobiose, dextrin, dulcitol, D-fructose, D-galactose, glycerol, glycogen (from oyster), meso-inositol, inulin, lactose, maltose, mannitol, D-mannose, melezitose, melibiose, raffinose, rhamnose, D-ribose, sucrose, salicin, sorbitol, L-sorbose, starch, trehalose, xylitol, and xylose.

Production of lipases. Lipase activity was tested on Tween 80 (Sierra, 1957) and on tributyrin (Collins \& Lyne, 1970).

Production of proteases. Proteolytic activity on gelatin was recorded on the following medium $\left(\mathrm{g}^{-1}\right)$ : meat extract (Oxoid), 3.0; peptone (Oxoid), 5.0; gelatin (Oxoid), 120.0. Plates were examined after 1, 2, 7 and $30 \mathrm{~d}$. Before reading, the plates were chilled for $2 \mathrm{~h}$. Plates that remained fluid were scored positive.

Casein breakdown was investigated in a medium consisting of $30 \%(\mathrm{v} / \mathrm{v})$ skim milk (Semper, Stockholm) and $1.5 \%(\mathrm{w} / \mathrm{v})$ agar (sterilized at $110^{\circ} \mathrm{C}$ for $\left.20 \mathrm{~min}\right)$. After incubation the plates were flooded with a $10 \%(\mathrm{w} / \mathrm{v})$ solution of $\mathrm{HgCl}_{2}$. Positive reaction was indicated by clearing around the confluent growth.

Egg-yolk reaction. Plates were poured with NA supplemented with $10 \%(\mathrm{v} / \mathrm{v})$ egg-yolk solution (Oxoid) and $1 \%(\mathrm{w} / \mathrm{v}) \mathrm{NaCl}$. Plates were examined for an opaque precipitation ('egg-yolk reaction') and for zones of clearing around the confluent growth due to lipolytic activity.

Hydrolysis of tyrosine. Plates were poured with NA supplemented with $5.0 \%(\mathrm{w} / \mathrm{v})$ tyrosine. Clearing around the confluent growth was scored positive.

Hydrolysis of starch. Plates were poured with NA supplemented with $0.3 \%(\mathrm{w} / \mathrm{v})$ soluble starch. Plates were flooded with Lugol's solution after incubation. Zones of clearing were scored positive.

Decomposition of hippurate. Plates were poured with the following medium $\left(\mathrm{g} \mathrm{l}^{-1}\right)$ : agar, $15 \cdot 0 ; \mathrm{NaCl}, 5 \cdot 0$; sodium hippurate, $3.0 ; \mathrm{NH}_{4} \mathrm{H}_{2} \mathrm{PO}_{4}, 1.0$; and phenol red, $0.001 \%(\mathrm{w} / \mathrm{v})$. The $\mathrm{pH}$ was adjusted to 6.9 and the 
medium was then sterilized at $110^{\circ} \mathrm{C}$ for $20 \mathrm{~min}$. Positive reaction was indicated by a red zone around the confluent growth.

Decomposition of arginine. This was tested as described by Thornley (1960).

Haemolysis on blood agar. Plates were poured with NA supplemented with $7 \%(\mathrm{v} / \mathrm{v})$ ox blood. The plates were observed daily for up to $4 \mathrm{~d}$ and haemolysis was recorded.

Denitrification. Plates were poured with the following medium $\left(\mathrm{g}^{-1}\right)$ : agar, 15.0; yeast extract (Oxoid), 5.0; $\mathrm{KNO}_{3}, 5 \cdot 0 ; \mathrm{K}_{2} \mathrm{HPO}_{4}, 1 \cdot 0$. The $\mathrm{pH}$ was adjusted to 6.8 and then the medium was sterilized at $121{ }^{\circ} \mathrm{C}$ for $15 \mathrm{~min}$. The plates were incubated anaerobically; denitrification was indicated by growth.

Miscellaneous tests. Methods and media for methyl red and Voges-Proskauer reactions, growth on alginate agar and on Simmon's citrate agar, deamination of phenylalanine, and production of DNAase, $\mathrm{H}_{2} \mathrm{~S}$ and urease were all as described by Edwards \& Ewing (1972). Production of RNAase was tested in the same base medium as DNAase, but supplemented with $0.2 \%$ or $2.0 \%$ (w/v) RNA (two tests).

Utilization of compounds as sole carbon source. A basal medium with the following composition ( $\left.\mathrm{g} \mathrm{l}^{-1}\right)$ : purified agar (Oxoid) 10.0; $\mathrm{Na}_{2} \mathrm{HPO}_{4}, 3 \cdot 0 ; \mathrm{KH}_{2} \mathrm{PO}_{4}, 2 \cdot 3 ; \mathrm{NH}_{4} \mathrm{Cl}, 1 \cdot 0 ; \mathrm{MgSO}_{4}, 0 \cdot 5 ; \mathrm{CaCl}_{2}, 0 \cdot 005 ; \mathrm{pH}$ adjusted to $6 \cdot 8$ before autoclaving $\left(121^{\circ} \mathrm{C}\right.$ for $\left.15 \mathrm{~min}\right)$ was aseptically supplemented with $0.13 \%(\mathrm{w} / \mathrm{v}$ or $\mathrm{v} / \mathrm{v})$ of the substances listed in Table 2. All substances which could be filtered were sterilized by filtering through a membrane filter (pore size $0.45 \mu \mathrm{m}$ ). The others were autoclaved or, if heat labile, pasteurized at $80-90^{\circ} \mathrm{C}$.

Plates with the supplemented basal medium were inoculated with the different strains by drawing a patch with a cotton swab. The number of patches (isolates) on the same plate was limited to five to avoid substrate exhaustion and/or cross-feeding reactions. All patches showing growth greater than the control (without carbon source) were regarded as positive. In a few cases 'mutants' developed in an otherwise negative test. These were considered as 'no consequence tests' and were not included in the computation of data.

Analysis of data. A total of 174 quantitative characters were codified as 0 , negative, 1 , positive, and 2 , of no consequence. None of the characteristics were the same for all the strains. Similarity coefficients using simple matching $\left[S_{M}=(m \times 100) /(n-n c)\right.$, where $m$ is the sum of positive and negative matches, $n$ is the total number of tests and $n c$ is the number of invalid tests] were obtained between every pair of strains.

The cluster analysis package 'Clustan' was used for the subsequent clustering (D. Wishart, Program Library Unit; version $1 \mathrm{c}$, release 2; Edinburgh University, 1978). Four methods with all possible combinations of similarity coefficients with 'hierarchy' options are applicable: (1) nearest neighbour, (2) furthest neighbour, (3) group average and (4) McQuitty's similarity analysis. Method (3) (also called average linkage) was chosen as the basis for the analysis and plotting of the dendrogram. The other methods were used to check the stability of the results.

\section{RESULTS}

\section{Clustering of the strains}

Of the total of 218 test strains, 198 formed 15 clusters. Figure 1 shows the clusters and the clustering pattern obtained by applying the group average method. The clusters formed at the similarity level of $88 \%$ were stable when the cluster analysis was checked by the furthest neighbour and McQuitty's similarity analysis methods. Thus, the three methods yielded the same major clusters and these merged in the same order. The differences were marginal and consisted of occasional reversals of the order in which some straggler strains joined the major clusters. The nearest neighbour method gave roughly the same results, but in this case all the clusters merged one by one directly into cluster 1 . This behaviour is inherent in the method, which tends to favour a cluster that is already large. The order of fusion remained the same for the major clusters but there were several reversals of order for the minor clusters and the stragglers.

The allocation of strains to clusters is shown in Table 1.

\section{Significant clusters}

Nine of the 15 clusters were regarded as significant. Thus, they were stable and either were large ( $>4$ strains) or included type or reference strains. The distribution of the physiological and biochemical characters among the defined taxa is shown in Table 2.

Cluster 1 (Pseudomonas fragi). This cluster included the type strain for $P$. fragi (ATCC 4973; strain no. 213). Typical strains utilized 55 out of 118 tested carbon sources. Of 
Table 1. Designation and source of strains

Lab no.

\begin{tabular}{|c|c|}
\hline & $\begin{array}{l}\text { Strains assigned to cluster } 1 \\
\quad(\text { Pseudomonas fragi) }\end{array}$ \\
\hline 1 & Pork \\
\hline 2 & Pork \\
\hline 27 & Pork \\
\hline 14 & Pork \\
\hline 53 & Pork \\
\hline 47 & Pork \\
\hline 186 & Pork \\
\hline 187 & Pork \\
\hline 86 & Beef \\
\hline 88 & Beef \\
\hline 93 & Beef \\
\hline 147 & Turkey \\
\hline 84 & Turkey \\
\hline 112 & High-pH beef \\
\hline 64 & Pork \\
\hline 13 & Pork \\
\hline 16 & Pork \\
\hline 18 & Pork \\
\hline 33 & Pork \\
\hline 15 & Pork \\
\hline 163 & Frozen hare meat, imported from Hungary \\
\hline 164 & Frozen hare meat, imported from Hungary \\
\hline 49 & Pork \\
\hline 52 & Pork \\
\hline 192 & Spoiled venison meat \\
\hline 79 & Beef \\
\hline 165 & Frozen hare meat, imported from Hungary \\
\hline 109 & Spoiled beef \\
\hline 19 & Bone marrow, pig \\
\hline 73 & Beef \\
\hline 3 & Pork \\
\hline 4 & Pork \\
\hline 38 & Prepacked pork \\
\hline 179 & Pork \\
\hline 185 & Pork \\
\hline 43 & Pork \\
\hline 48 & Pork \\
\hline 50 & Pork \\
\hline 68 & Pork \\
\hline 98 & Spoiled beef \\
\hline 197 & Pork \\
\hline 182 & Pork \\
\hline 194 & Spoiled elk meat \\
\hline 200 & $\begin{array}{l}\text { Frozen antelope meat, imported from } \\
\text { USSR }\end{array}$ \\
\hline 199 & $\begin{array}{l}\text { Frozen antelope meat, imported from } \\
\text { USSR }\end{array}$ \\
\hline 146 & Turkey \\
\hline 89 & Beef \\
\hline 195 & Spoiled elk meat \\
\hline 71 & Beef \\
\hline 188 & Pork \\
\hline 46 & Pork \\
\hline 51 & Pork \\
\hline 72 & Beef \\
\hline 90 & Beef \\
\hline 55 & Pork \\
\hline 116 & Beef \\
\hline 77 & Beef \\
\hline 66 & Pork \\
\hline
\end{tabular}

Lab no. Source/collection no.

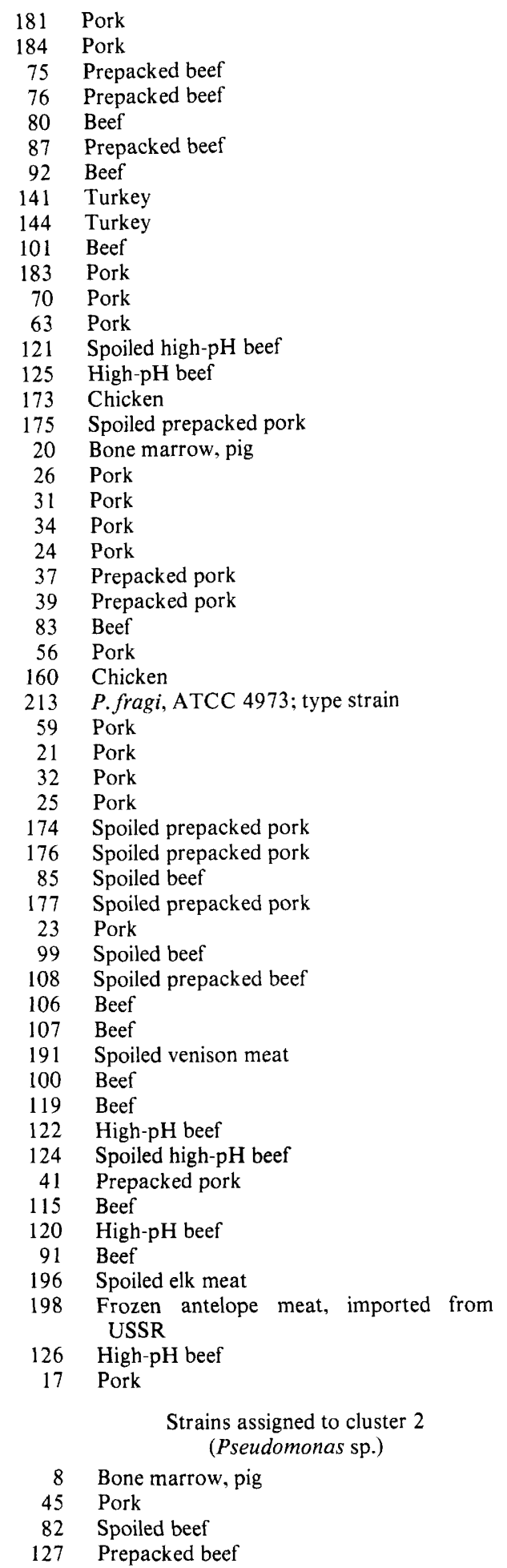


Table 1 (continued)

Lab no.

$\begin{aligned} 128 & \text { Prepacked beef } \\ 133 & \text { Prepacked beef } \\ 139 & \text { Prepacked beef } \\ 131 & \text { Prepacked beef } \\ 132 & \text { Prepacked beef } \\ 136 & \text { Prepacked beef } \\ 138 & \text { Prepacked beef } \\ 135 & \text { Prepacked beef } \\ 130 & \text { Prepacked beef } \\ 140 & \text { Prepacked beef } \\ 134 & \text { Prepacked beef } \\ 178 & \text { Prepacked beef } \\ 137 & \text { Prepacked beef } \\ 65 & \text { Pork } \\ 129 & \text { Prepacked beef } \\ 102 & \text { Spoiled beef } \\ 97 & \text { Prepacked beef }\end{aligned}$

Strains assigned to cluster 3 (Pseudomonas sp.)

78 Beef

162 Frozen hare meat, imported from Hungary

Strains assigned to cluster 4 (Pseudomonas sp.)

5 Pork

6 Pork

7 Pork

81 Prepacked beef

Strains assigned to cluster 5 (Pseudomonas sp.)

36 Slimy bone marrow, pig

142 Turkey

Strains assigned to cluster 6 (Pseudomonas sp.)

9 Bone marrow, pig

10 Bone marrow, pig

153 Chicken

Strains assigned to cluster 7

( $P$. fluorescens biotype III)

104 Beef

105 Beef

117 Beef

$212 P$. fluorescens biotype III, ATCC 17400 (R. Y. Stainer 18)

143 Turkey

206 P. fluorescens biotype III, DSM 50124

(R. Y. Stainer 214)

154 Chicken

Strains assigned to cluster 8

(P. fluorescens biotype I)

11 Pork

12 Pork

54 Pork

22 Pork

149 Chicken

151 Chicken

217 P.putida DSM 50906

Lab no. Source/collection no.

168

169

150

152

158

167

155

159

210

123

171
Chicken

Chicken

Chicken

Chicken

Chicken

Chicken

Chicken

Chicken

P. fluorescens biotype I, ATCC 13525

(R. Y. Stanier 193); type strain.

Strains assigned to cluster 9 ( $P$. aureofaciens/P. chlororaphis)

$P$. aureofaciens, DSM 50082

$P$. aureofaciens, DSM 50139 (R. Y. Stanier 36)

P. chloraphis, DSM $50083=$ ATCC 9446

(R. Y. Stanier 30); type strain

Strains assigned to cluster 10 (Pseudomonas $\mathrm{sp}$. )

High-pH beef

Chicken

Strains assigned to cluster 11

(P. fluorescens biotype II)

P. fluorescens biotype II, DSM 50106 (R. Y. Stanier 411)

P. fluorescens biotype II, DSM 50108

(R. Y. Stanier 108)

P. fluorescens, A TCC 949

Strains assigned to cluster 12 (P. putida biotype I)

$P$. fluorescens, ATCC 11172

P. putida biotype I, DSM 50208 (R. Y. Stanier 111)

P. putida biotype I, DSM 50198 (R. Y. Stanier 77)

$P$. putida biotype I, DSM $50202=$ ATCC 12633 (R. Y. Stanier 90); type strain.

Strains assigned to cluster 13 (Pseudomonas sp.)

Pork

Chicken

High-pH beef

Chicken

Strains assigned to cluster 14

(Alteromonas putrefaciens)

Slimy bone marrow, pig

Pork

Pork

Turkey

Pork

Pork

Pork

Prepacked high-pH beef

Prepacked high-pH beef

Prepacked high-pH beef 
Table 1 (continued)

Lab no.

\begin{tabular}{|c|c|}
\hline & $\begin{array}{l}\text { Strains assigned to cluster } 15 \\
\text { (Aeromonas hydrophila) }\end{array}$ \\
\hline 29 & Slimy bone marrow, pig \\
\hline & Prepacked pork \\
\hline 60 & Pork \\
\hline 61 & Pork \\
\hline 148 & Turkey \\
\hline
\end{tabular}

Strains not assigned to clusters

$$
\begin{aligned}
& \text { Beef } \\
& \text { Spoiled elk meat } \\
& \text { Prepacked pork } \\
& \text { Pork } \\
& \text { Spoiled venison meat } \\
& \text { Chicken }
\end{aligned}
$$

Lab no. Source/collection no.

the 112 strains, 110 were unable to produce fluorescent pigments, and 105 of the 112 did not produce gelatinase. Some critical tests whereby $P$. fragi may be separated from related taxa are listed in Table 3.

Cluster 2. This cluster could be described as intermediate between $P$. fragi and $P$. fluorescens. The resemblance to $P$. fluorescens is indicated by the fact that 10 of the 21 strains produced fluorescent pigments and 20 produced gelatinase. However, the strains clustered next to $P$. fragi and utilized significantly fewer carbon sources (45) than P. fluorescens (65).

We would predict that cluster 2 represents a new species, but it requires at least a guanine plus cytosine analysis before this can be verified.

Cluster 7 ( $P$. fluorescens biotype III). This cluster included the two biotype III reference strains DSM 50124 (no. 206) and ATCC 17400 (no. 212), both described by Stanier et al. (1966), who used the term biotype C. All the clustered strains met the description of biotype III (Doudoroff \& Palleroni, 1974) with the exception of the utilization of L-arabinose. Six of the strains in our study were able to utilize this compound.

Cluster 8 ( $P$. fluorescens biotype I). This cluster included the type strain for P. fluorescens, ATCC 13525 (no. 210). Ten of the 14 field strains were isolated from chicken. All the strains met the description of biotype I (Doudoroff \& Palleroni, 1974).

Cluster $9(P$. aureofaciens/ $P$. chlororaphis). This cluster included only type and reference strains, which all met the descriptions of Doudoroff \& Palleroni (1974): P. chlororaphis DSM 50083 (no. $203=$ ATCC 9446) is the type strain and $P$. aureofaciens strain DSM 50139 (no. 202) was described by Stanier et al. (1966) as $P$. fluorescens biotype E.

Cluster 11 ( $P$. fluorescens biotype II). This cluster consisted only of reference strains, which all met the description of Doudoroff \& Palleroni (1974). The strains DSM 50106 and DSM 50108 (nos 204 and 205, respectively) were described by Stanier et al. (1966) as biotype $\mathrm{B}$.

Cluster 12 (P. putida biotype I). The cluster consisted only of type and reference strains, all with high resemblance to the description of Doudoroff \& Palleroni (1974). Three of the strains were described by Stanier et al. (1966), including the type strain DSM 50202 (no. 215 $=$ ATCC 12633). The fourth strain, ATCC 11172 (no. 209), was labelled as a P. fluorescens (ATCC Catalogue of Strains I, 14th edn, 1980). It should be pointed out that after prolonged incubation this strain was able to denitrify, a character not previously recorded in P.putida.

Cluster 14 (Alteromonas putrefaciens). This cluster, which consisted only of field strains, differs distinctly from the other pseudomonad strains examined. Thus, the strains utilized only 10 carbon sources for growth and produced only small amounts or no acid at all from the tested carbohydrates. The cluster could easily be separated from the other psychrotrophic 
pseudomonads by the following: ability to produce $\mathrm{H}_{2} \mathrm{~S}$; pink pigmentation; inability to produce arginine dihydrolase; and ability to produce DNAase (10 out of 14).

Cluster 15 (Aeromonas hydrophila). This cluster is not related to the Pseudomonas strains. The test results (Table 2) match the description for $A$. hydrophila biotype I (subsp. hydrophila; Popoff \& Veron 1976).

\section{Insignificant clusters}

Clusters 3-6, 10 and 13 may be regarded as insignificant. They consisted of 2-4 isolates and are mostly intermediates between named species or within the P. fluorescens complex.

Cluster 4 (4 strains) was unstable as it changed position when the different methods of cluster analysis were applied.

Cluster 6 ( 3 strains) joined the $P$. fluorescens biotype III cluster (cluster 7 ) at the $85 \%$ level and might be regarded as a subgroup of biotype III. Similar organisms were included in biotype C of Stanier et al. (1966).

Cluster 13 (4 strains) comprised strains grouped together due to their almost completely negative response to the utilization tests. If negative matches were excluded, the cluster disintegrated.

Three reference strains-P. fluorescens ATCC 17397 (no. 211), P. fluorescens biotype IV, DSM 50415 (no. 207) and P. putida biotype II, DSM 50222 (no. 218)-were stragglers. The $P$. fluorescens biotype IV strain joined the $P$. fluorescens complex as the last strain at the $81 \%$ level.

\section{DISCUSSION}

The utilization tests of the present study followed closely the procedure of Stanier et al. (1966). However, the basal medium was that described by Palleroni \& Doudoroff (1972) (citrate eliminated) and the incubation temperature was $25^{\circ} \mathrm{C}$ instead of $30^{\circ} \mathrm{C}$. The ability to produce acid from 30 different compounds was tested. Most of these were also used in the utilization tests and it could be argued that the same features were tested twice. However, there were often discrepancies between the ability of an organism to utilize a particular compound and to produce acid from it. Thus, an organism may be positive in the utilization test but negative in the acid production test or vice versa. This has also been pointed out by Palleroni \& Doudoroff (1972).

Cluster 1 was designated as P. fragi. The name fragi (Bacterium fragi) was originally used by Eichholz (1902) on a psychrotrophic milk spoiling organism which gave off a strawberry odour. The organism was considered by Hussong et al. (1937) to be identical to an organism called Pseudomonas fragariae by Grüber (1902). Pseudomonas fragi was isolated from various sources (milk, cream, cheese, butter, sheep fat and water) and reported to be a non-fluorescent, proteolytic and 'May apple'-smelling organism (Hussong et al., 1937). The organism has been further described by Breed et al. (1948) and Pereira \& Morgan (1957), and a neotype strain for P. fragi (ATCC 4973) was proposed by Lysenko (1961); this has since become the type strain (Skerman et al., 1980). This particular strain has since then been used as test organism in a number of studies, and has not only been connected with the spoilage of dairy products but also that of meat (Tarrant et al., 1973; Enfors \& Molin, 1981) and fish (Florin, 1972). In spite of this, taxonomic information on $P$. fragi is sparse and too limited to provide a base for differentiation from other psychrotrophic Pseudomonas species. Consequently, the organism is not described in the eighth edition of Bergey's Manual of Determinative Bacteriology. Nevertheless, cluster 1 seems to have much in common with the descriptions of $P$. fragi. The exceptions are the proteolytic activity on gelatin and the acid production on maltose. However, earlier methodological descriptions are vague, making it 
Table 2. Percentage frequencies of positive characters found in the major clusters and clusters containing type and reference strains

All strains had the following properties: Gram-negative; oxidase positive; motile rod morphology; growth at $3 \%$ but not at $6 \% \mathrm{NaCl}$; no growth at $42{ }^{\circ} \mathrm{C}$; negative for methyl red reaction; no growth on alginate; negative for deamination of phenylalanine; negative for acid production from adonitol, amygdalin, dulcitol, meso-inositol and inulin; negative for utilization of $\mathrm{D}$-fucose, butyrate, maleate, pimelate, glycollate, cis-aconitate, ethylene glycol, L-mandelate, testosterone, DL-norvaline, $\alpha$-amylamine, 2-aminoethanol and DL- $\alpha$-aminobutyrate.

\begin{tabular}{|c|c|c|c|c|c|c|c|c|c|}
\hline & $\frac{\overrightarrow{0}}{\vec{D}^{\circ}}$ & 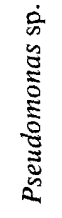 & 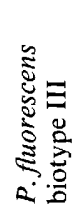 & 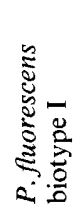 & 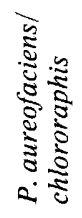 & 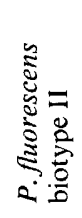 & 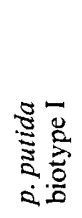 & 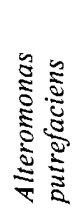 & 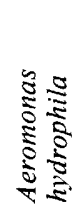 \\
\hline $\begin{array}{l}\text { Cluster no. } \\
\text { No. of strains }\end{array}$ & $\begin{array}{c}1 \\
112\end{array}$ & $\begin{array}{c}2 \\
21\end{array}$ & $\begin{array}{l}7 \\
7\end{array}$ & $\begin{array}{c}8 \\
16\end{array}$ & $\begin{array}{l}9 \\
3\end{array}$ & $\begin{array}{c}11 \\
3\end{array}$ & $\begin{array}{c}12 \\
4\end{array}$ & $\begin{array}{l}14 \\
10\end{array}$ & $\begin{array}{c}15 \\
5\end{array}$ \\
\hline $\begin{array}{l}\text { Colonial morphology: } \\
\text { Fluorescent pigments } \\
\text { Phenazine pigments } \\
\text { Pink pigments } \\
\text { Yellow pigments } \\
\beta \text {-Haemolysis }\end{array}$ & $\begin{array}{l}2 \\
0 \\
0 \\
2 \\
0\end{array}$ & $\begin{array}{r}48 \\
0 \\
0 \\
0 \\
0\end{array}$ & $\begin{array}{r}86 \\
0 \\
0 \\
0 \\
0\end{array}$ & $\begin{array}{r}75 \\
0 \\
0 \\
0 \\
0\end{array}$ & $\begin{array}{r}100 \\
100 \\
0 \\
0 \\
0\end{array}$ & $\begin{array}{r}100 \\
0 \\
0 \\
0 \\
0\end{array}$ & $\begin{array}{r}100 \\
0 \\
0 \\
0 \\
0\end{array}$ & $\begin{array}{r}0 \\
0 \\
100 \\
0 \\
10\end{array}$ & $\begin{array}{r}0 \\
0 \\
0 \\
0 \\
100\end{array}$ \\
\hline $\begin{array}{c}\text { Growth at: } \\
4{ }^{\circ} \mathrm{C} \\
37^{\circ} \mathrm{C}\end{array}$ & $\begin{array}{r}100 \\
0\end{array}$ & $\begin{array}{r}100 \\
0\end{array}$ & $\begin{array}{r}100 \\
0\end{array}$ & $\begin{array}{r}100 \\
6\end{array}$ & $\begin{array}{r}100 \\
33\end{array}$ & $\begin{array}{r}100 \\
0\end{array}$ & $\begin{array}{r}100 \\
50\end{array}$ & $\begin{array}{r}80 \\
0\end{array}$ & $\begin{array}{l}100 \\
100\end{array}$ \\
\hline $\begin{array}{l}\text { Biochemical tests: } \\
\text { Arginine hydrolysis } \\
\text { Citrate, Simmon's } \\
\text { Hippurate hydrolysis } \\
\mathrm{H}_{2} \mathrm{~S} \\
\text { Indole } \\
\mathrm{NO}_{3} \rightarrow \mathrm{N}_{2} \\
\text { Urease } \\
\text { Voges-Proskauer }\end{array}$ & $\begin{array}{r}99 \\
99 \\
90 \\
0 \\
3 \\
4 \\
71 \\
0\end{array}$ & $\begin{array}{r}100 \\
100 \\
62 \\
0 \\
0 \\
0 \\
67 \\
0\end{array}$ & $\begin{array}{r}100 \\
100 \\
71 \\
0 \\
0 \\
100 \\
14 \\
0\end{array}$ & $\begin{array}{r}94 \\
94 \\
88 \\
0 \\
0 \\
6 \\
94 \\
0\end{array}$ & $\begin{array}{r}100 \\
100 \\
67 \\
0 \\
0 \\
0 \\
100 \\
0\end{array}$ & $\begin{array}{r}100 \\
100 \\
100 \\
0 \\
0 \\
100 \\
100 \\
0\end{array}$ & $\begin{array}{r}100 \\
100 \\
100 \\
0 \\
0 \\
25 \\
0 \\
0\end{array}$ & $\begin{array}{r}0 \\
0 \\
50 \\
90 \\
0 \\
40 \\
40 \\
0\end{array}$ & $\begin{array}{r}100 \\
80 \\
60 \\
0 \\
100 \\
0 \\
0 \\
100\end{array}$ \\
\hline $\begin{array}{l}\text { Degradation tests: } \\
\text { Casein } \\
\text { DNA } \\
\text { Egg-yolk reaction } \\
\text { Egg-yolk clearing } \\
\text { Gelatin } \\
\text { RNA } \\
\text { Starch } \\
\text { Tributyrin } \\
\text { Tween } 80 \\
\text { Tyrosine }\end{array}$ & $\begin{array}{r}1 \\
0 \\
6 \\
14 \\
6 \\
0 \\
0 \\
75 \\
2 \\
98\end{array}$ & $\begin{array}{r}0 \\
0 \\
19 \\
76 \\
95 \\
0 \\
0 \\
75 \\
0 \\
95\end{array}$ & $\begin{array}{r}100 \\
0 \\
100 \\
86 \\
100 \\
0 \\
0 \\
100 \\
100 \\
86\end{array}$ & $\begin{array}{r}56 \\
0 \\
94 \\
56 \\
88 \\
0 \\
6 \\
100 \\
50 \\
100\end{array}$ & $\begin{array}{r}100 \\
0 \\
100 \\
100 \\
100 \\
0 \\
0 \\
100 \\
100 \\
100\end{array}$ & $\begin{array}{r}0 \\
0 \\
33 \\
67 \\
33 \\
0 \\
0 \\
100 \\
0 \\
67\end{array}$ & $\begin{array}{r}0 \\
0 \\
0 \\
0 \\
0 \\
0 \\
0 \\
100 \\
0 \\
100\end{array}$ & $\begin{array}{r}10 \\
70 \\
20 \\
100 \\
100 \\
40 \\
0 \\
80 \\
80 \\
100\end{array}$ & $\begin{array}{r}100 \\
60 \\
40 \\
100 \\
100 \\
80 \\
80 \\
80 \\
100 \\
20\end{array}$ \\
\hline $\begin{array}{l}\text { Acid from: } \\
\text { L-Arabinose } \\
\text { Cellobiose } \\
\text { Dextrin } \\
\text { D-Fructose } \\
\text { D-Galactose } \\
\text { D-Glucose (aerobic) } \\
\text { D-Glucose (anaerobic) } \\
\text { Glycerol } \\
\text { Glycogen } \\
\text { Lactose } \\
\text { Maltose } \\
\text { Mannitol } \\
\text { D-Mannose }\end{array}$ & $\begin{array}{r}100 \\
99 \\
0 \\
0 \\
100 \\
100 \\
0 \\
7 \\
0 \\
16 \\
100 \\
4 \\
100\end{array}$ & $\begin{array}{r}100 \\
100 \\
0 \\
0 \\
100 \\
100 \\
0 \\
0 \\
0 \\
5 \\
95 \\
0 \\
95\end{array}$ & $\begin{array}{r}100 \\
14 \\
0 \\
0 \\
100 \\
100 \\
0 \\
0 \\
0 \\
0 \\
0 \\
0 \\
100\end{array}$ & $\begin{array}{r}100 \\
13 \\
0 \\
0 \\
100 \\
100 \\
0 \\
13 \\
0 \\
0 \\
6 \\
19 \\
100\end{array}$ & $\begin{array}{r}67 \\
0 \\
0 \\
0 \\
100 \\
100 \\
0 \\
0 \\
0 \\
0 \\
0 \\
0 \\
100\end{array}$ & $\begin{array}{r}100 \\
0 \\
0 \\
0 \\
100 \\
100 \\
0 \\
0 \\
0 \\
0 \\
0 \\
0 \\
100\end{array}$ & $\begin{array}{r}100 \\
0 \\
0 \\
0 \\
100 \\
100 \\
0 \\
0 \\
0 \\
0 \\
0 \\
0 \\
100\end{array}$ & $\begin{array}{r}20 \\
0 \\
0 \\
0 \\
10 \\
20 \\
0 \\
0 \\
0 \\
0 \\
10 \\
0 \\
10\end{array}$ & $\begin{array}{r}100 \\
100 \\
100 \\
100 \\
100 \\
100 \\
100 \\
100 \\
100 \\
60 \\
100 \\
100 \\
100\end{array}$ \\
\hline
\end{tabular}


Table 2 (continued)

$\begin{array}{lrrrrrrrrr}\text { Cluster no. } & 1 & 2 & 7 & 8 & 9 & 11 & 12 & 14 & 15 \\ \text { Melezitose } & 0 & 5 & 0 & 0 & 0 & 0 & 0 & 0 & 0 \\ \text { Melibiose } & 100 & 95 & 100 & 100 & 100 & 33 & 50 & 0 & 0 \\ \text { Raffinose } & 0 & 0 & 0 & 0 & 67 & 0 & 0 & 0 & 0 \\ \text { Rhamnose } & 8 & 10 & 57 & 0 & 0 & 0 & 0 & 0 & 0 \\ \text { D-Ribose } & 99 & 95 & 100 & 100 & 100 & 100 & 0 & 0 & 100 \\ \text { Sucrose } & 0 & 0 & 0 & 69 & 100 & 67 & 0 & 0 & 100 \\ \text { Salicin } & 0 & 0 & 0 & 0 & 0 & 0 & 0 & 0 & 100 \\ \text { Sorbitol } & 1 & 0 & 0 & 63 & 0 & 100 & 0 & 0 & 40 \\ \text {-Sorbose } & 0 & 0 & 0 & 6 & 0 & 0 & 0 & 0 & 0 \\ \text { Starch } & 0 & 0 & 0 & 0 & 0 & 0 & 0 & 0 & 100 \\ \text { Trehalose } & 0 & 0 & 0 & 0 & 0 & 0 & 0 & 0 & 100 \\ \text { Xylitol } & 1 & 5 & 0 & 6 & 0 & 0 & 0 & 0 & 0 \\ \text { Xylose } & 99 & 100 & 100 & 100 & 67 & 100 & 100 & 0 & 0 \\ \text { Trowh } & & & & & & & & & 0\end{array}$

Growth on sole carbon source:

Carbohydrates:

D-Arabinose

L-Arabinose

Cellobiose

D-Fructose

D-Galactose

Gluconate

D-Glucose

Lactose

Maltose

D-Mannose

Mucate

L-Rhamnose

D-Ribose

Saccharate

Salicin

Starch

Sucrose

Trehalose

D-Xylose

$\begin{array}{rrrrrrrrr}94 & 52 & 29 & 13 & 0 & 0 & 50 & 0 & 0 \\ 66 & 91 & 86 & 100 & 67 & 100 & 75 & 20 & 100 \\ 1 & 10 & 67 & 0 & 0 & 100 & 75 & 0 & 100 \\ 99 & 100 & 100 & 100 & 100 & 100 & 100 & 0 & 100 \\ 26 & 0 & 86 & 100 & 67 & 100 & 25 & 0 & 100 \\ 100 & 100 & 100 & 100 & 100 & 100 & 100 & 70 & 100 \\ 100 & 100 & 100 & 100 & 100 & 100 & 100 & 100 & 100 \\ 0 & 0 & 0 & 0 & 0 & 0 & 0 & 0 & 40 \\ 26 & 14 & 29 & 0 & 0 & 100 & 75 & 100 & 100 \\ 68 & 0 & 100 & 100 & 100 & 100 & 0 & 0 & 100 \\ 62 & 0 & 86 & 100 & 100 & 100 & 100 & 0 & 0 \\ 1 & 5 & 86 & 0 & 0 & 100 & 50 & 0 & 0 \\ 100 & 19 & 100 & 100 & 100 & 100 & 25 & 0 & 100 \\ 93 & 0 & 0 & 73 & 100 & 100 & 100 & 0 & 20 \\ 1 & 0 & 14 & 0 & 0 & 0 & 0 & 0 & 100 \\ 1 & 0 & 14 & 0 & 33 & 0 & 50 & 70 & 100 \\ 12 & 0 & 14 & 56 & 100 & 67 & 0 & 30 & 100 \\ 90 & 10 & 100 & 93 & 100 & 100 & 0 & 30 & 100 \\ 100 & 5 & 0 & 88 & 0 & 67 & 25 & 0 & 0\end{array}$

Fatty acids:

Acetate

iso-Butyrate

Caprate

Caproate

Caprylate

Heptanoate

Pelargonate

Propionate

Valerate

iso-Valerate

$\begin{array}{rrrrrrrrr}98 & 100 & 100 & 94 & 100 & 100 & 100 & 10 & 100 \\ 0 & 0 & 0 & 0 & 0 & 0 & 33 & 0 & 0 \\ 90 & 95 & 100 & 100 & 100 & 67 & 100 & 10 & 40 \\ 13 & 15 & 100 & 69 & 100 & 0 & 100 & 0 & 0 \\ 96 & 95 & 100 & 100 & 100 & 100 & 100 & 0 & 0 \\ 98 & 100 & 100 & 100 & 100 & 100 & 100 & 0 & 100 \\ 95 & 100 & 100 & 100 & 100 & 67 & 100 & 0 & 0 \\ 94 & 100 & 100 & 100 & 100 & 100 & 100 & 0 & 0 \\ 28 & 0 & 0 & 13 & 0 & 0 & 0 & 0 & 0 \\ 0 & 0 & 0 & 6 & 0 & 0 & 100 & 0 & 0\end{array}$

Dicarboxylic acids:

Adipate

Glutarate

Malonate

Sebacate

Suberate

Succinate

Hydroxyacids:

DL-Glycerate

DL- $\beta$-Hydroxybutyrate

Hydroxymethylglutarate

DL-Lactate

D-Malate

L-Malate

$\begin{array}{rrrrrrrrr}1 & 5 & 50 & 0 & 0 & 0 & 0 & 0 & 0 \\ 100 & 100 & 100 & 100 & 100 & 100 & 100 & 0 & 20 \\ 1 & 0 & 14 & 31 & 0 & 0 & 50 & 0 & 0 \\ 0 & 0 & 57 & 0 & 0 & 0 & 0 & 0 & 0 \\ 1 & 0 & 14 & 0 & 0 & 0 & 0 & 0 & 20 \\ 100 & 100 & 100 & 100 & 100 & 100 & 100 & 90 & 100\end{array}$

$\begin{array}{rrrrrrrrr}100 & 91 & 100 & 100 & 100 & 100 & 100 & 70 & 80 \\ 83 & 5 & 100 & 100 & 100 & 100 & 100 & 0 & 0 \\ 0 & 0 & 0 & 81 & 0 & 100 & 0 & 0 & 0 \\ 100 & 100 & 100 & 100 & 100 & 100 & 100 & 50 & 0 \\ 36 & 0 & 0 & 0 & 0 & 0 & 100 & 0 & 0 \\ 67 & 91 & 86 & 50 & 100 & 100 & 100 & 0 & 20\end{array}$


Table 2 (continued)

Cluster no.

D-Tartrate

L-Tartrate

meso-Tartrate

$\begin{array}{rll}1 & 2 & 7 \\ 2 & 0 & \\ 0 & 0 & 0 \\ 82 & 0 & 0\end{array}$

8

Miscellaneous organic acids:

Citraconate

Citrate

Itaconate

Laevulinate

2-Oxoglutarate

$\begin{array}{rrr}0 & 0 & 29 \\ 100 & 100 & 100 \\ 63 & 0 & 43 \\ 0 & 0 & 0 \\ 100 & 100 & 100\end{array}$

6
100
81
6
100

0
100

33

100

67

100

100

100

11

12

$14 \quad 15$

Polyalcohols and glycols:

Adonitol

Butane-2,3-diol

Glycerol

meso-Inositol

Mannitol

Propane-1,2-diol

Sorbitol

$\begin{array}{rrrr}1 & 0 & 86 & 94 \\ 1 & 0 & 86 & 13 \\ 100 & 100 & 100 & 100 \\ 17 & 95 & 100 & 100 \\ 66 & 0 & 100 & 100 \\ 3 & 0 & 86 & 0 \\ 3 & 0 & 0 & 94\end{array}$

$\begin{array}{rr}0 & 0 \\ 100 & 100 \\ 100 & 100 \\ 100 & 100 \\ 100 & 100 \\ 0 & 100 \\ 0 & 100\end{array}$

$\begin{array}{rrr}0 & 0 & 0 \\ 100 & 0 & 0 \\ 100 & 0 & 100 \\ 0 & 0 & 0 \\ 0 & 0 & 100 \\ 100 & 0 & 0 \\ 0 & 0 & 60\end{array}$

Alcohols:

iso-Butanol

$N$-Butanol

0
20
2
0
4

$\begin{array}{rrr}0 & 71 & 0 \\ 91 & 57 & 31 \\ 5 & 71 & 0 \\ 0 & 14 & 0 \\ 5 & 14 & 0\end{array}$

$\begin{array}{rrr}0 & 100 & 100 \\ 100 & 100 & 100 \\ 0 & 100 & 75 \\ 0 & 0 & 100 \\ 0 & 67 & 25\end{array}$

$N$-Propanol

Non-nitrogenous aromatic and other cyclic compounds:

Benzoate
Benzoylformate
$m$-Hydroxybenzoate
$o$-Hydroxybenzoate
$p$-Hydroxybenzoate
Phenol
Phenylacetate
D-Quinate

$\begin{array}{rl}85 & 67 \\ 0 & \\ 0 \\ 4 \\ 96 \\ 0 \\ 2 \\ 97\end{array}$

67
0
0
0
5
0
0
5

Aliphatic amino acids:

D- $\alpha$-Alanine
L- $\alpha$-Alanine
$\beta$-Alanine
$\gamma$-Aminobutyrate
DL- $\alpha$-Aminovalerate
$\partial$-Aminovalerate
DL-Arginine
L-Aspartate
DL-Citrulline
L-Glutamate
Glycine
L-Isoleucine
DL-Norleucine
L-Leucine
L-Lysine
DL-Ornithine
L-Serine
L-Threonine
L-Valine

$\begin{array}{rrr}100 & 100 & 100 \\ 100 & 100 & 100 \\ 98 & 100 & 100 \\ 98 & 100 & 100 \\ 0 & 0 & 0 \\ 51 & 100 & 100 \\ 99 & 100 & 100 \\ 100 & 100 & 100 \\ 1 & 0 & 100 \\ 100 & 100 & 100 \\ 75 & 0 & 0 \\ 81 & 76 & 100 \\ 1 & 0 & 0 \\ 99 & 100 & 100 \\ 7 & 0 & 29 \\ 96 & 95 & 100 \\ 4 & 0 & 100 \\ 0 & 0 & 0 \\ 85 & 100 & 100\end{array}$

$\begin{array}{rr}44 & 100 \\ 0 & 100 \\ 0 & 33 \\ 0 & 0 \\ 100 & 100 \\ 0 & 0 \\ 0 & 67 \\ 100 & 100\end{array}$

$\begin{array}{rrrr}0 & 100 & 0 & 0 \\ 0 & 75 & 0 & 0 \\ 67 & 75 & 0 & 0 \\ 0 & 0 & 0 & 0 \\ 100 & 100 & 0 & 0 \\ 0 & 50 & 0 & 0 \\ 0 & 75 & 0 & 0 \\ 100 & 100 & 10 & 20\end{array}$

Amino acids and related compounds:

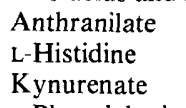

L-Phenylalanine

$\begin{array}{rrrrrrrrr}2 & 0 & 100 & 100 & 100 & 100 & 0 & 0 & 0 \\ 100 & 100 & 100 & 100 & 100 & 67 & 100 & 0 & 100 \\ 8 & 0 & 100 & 75 & 33 & 0 & 50 & 0 & 0 \\ 97 & 91 & 100 & 38 & 67 & 67 & 100 & 0 & 0\end{array}$


Table 2 (continued)

\begin{tabular}{|c|c|c|c|c|c|c|c|c|c|}
\hline Cluster no. & 1 & 2 & 7 & 8 & 9 & 11 & 12 & 14 & 15 \\
\hline L-Proline & 100 & 100 & 100 & 100 & 100 & 100 & 100 & 0 & 20 \\
\hline D-Tryptophan & 0 & 0 & 0 & 6 & 0 & 0 & 0 & 0 & 0 \\
\hline L-Tryptophan & 0 & 0 & 100 & 100 & 100 & 100 & 0 & 0 & 0 \\
\hline L-Tyrosine & 100 & 95 & 100 & 100 & 100 & 100 & 100 & 10 & 80 \\
\hline \multicolumn{10}{|l|}{ Amines: } \\
\hline Benzylamine & 0 & 0 & 0 & 0 & 0 & 0 & 100 & 10 & 0 \\
\hline Butylamine & 0 & 0 & 0 & 0 & 0 & 0 & 100 & 0 & 0 \\
\hline Ethanolamine & 96 & 95 & 86 & 94 & 100 & 67 & 100 & 30 & 80 \\
\hline Histamine & 4 & 0 & 0 & 40 & 100 & 0 & 100 & 0 & 0 \\
\hline Putrescine & 100 & 100 & 100 & 100 & 100 & 100 & 100 & 40 & 100 \\
\hline Spermine & 100 & 100 & 86 & 100 & 100 & 100 & 100 & 10 & 20 \\
\hline Tryptamine & 0 & 0 & 29 & 0 & 0 & 100 & 0 & 0 & 0 \\
\hline \multicolumn{10}{|c|}{ Miscellaneous nitrogenous compounds: } \\
\hline Acetamide & 0 & 0 & 0 & 0 & 0 & 0 & 25 & 0 & 0 \\
\hline Betaine & 100 & 86 & 100 & 100 & 100 & 100 & 100 & 10 & 20 \\
\hline Hippurate & 86 & 5 & 14 & 13 & 0 & 0 & 100 & 10 & 20 \\
\hline Nicothinate & 16 & 0 & 0 & 19 & 0 & 0 & 100 & 0 & 0 \\
\hline Sarcosine & 76 & 81 & 60 & 88 & 100 & 100 & 100 & 0 & 20 \\
\hline Trigonelline & 1 & 0 & 0 & 0 & 0 & 33 & 100 & 0 & 0 \\
\hline
\end{tabular}

Table 3. Simplified scheme for the differentiation of P. fragi, cluster 2, P. fluorescens and P. putida

Key:,$- 10 \%$ or less of strains positive;,$+ 90 \%$ or more of strains positive; $v$, variable reaction (percentage of positive strains shown in parentheses); $d$, differs between biotypes.

$\begin{array}{lcccc} & P . \text { fragi }^{*} & \text { Cluster 2* } & \text { P. fluorescens } & \text { P. putida } \\ \text { Fluorescent pigments } & - & \mathrm{v}(48) & + & + \\ \text { Gelatinase } & - & + & + & - \\ \text { Acid from cellobiose } & & + & - & - \\ \begin{array}{l}\text { and maltose } \\ \text { Utilization of: }\end{array} & + & - & \mathrm{d} & + \\ \text { Saccharate } & + & - & + & - \\ \text { Trehalose } & + & + & + & + \\ \text { meso-Inositol } & \mathrm{v}(17) & - & - & \\ \text { Benzylamine } & - & & & \\ \quad \text { * Based on the present study. } & \end{array}$

difficult to compare the results with the present ones. It may be pointed out that the gelatinase test applied in the present study gives a positive reaction only at a comparatively high activity. Pseudomonas fragi seems to be widely distributed in nature and is apparently the most important part of the microflora of refrigerated meat.

Cluster 2 strains differed significantly from $P$. fragi as well as the $P$. fluorescens complex (Fig. 1). This taxon was after $P$. fragi the most commonly occurring among the field isolates.

All biotypes of $P$. fluorescens described in the eighth edition of Bergey's Manual of Determinative Bacteriology are represented in the present study. Stanier et al. (1966) divided $P$. fluorescens into six well-defined biotypes (A to F) and one provisional biotype (G). Biotypes A, B, C and F are in Bergey's Manual of Determinative Bacteriology (8th edition) represented by biotypes I, II, III and IV, respectively, and biotypes D and E are listed as $P$. 


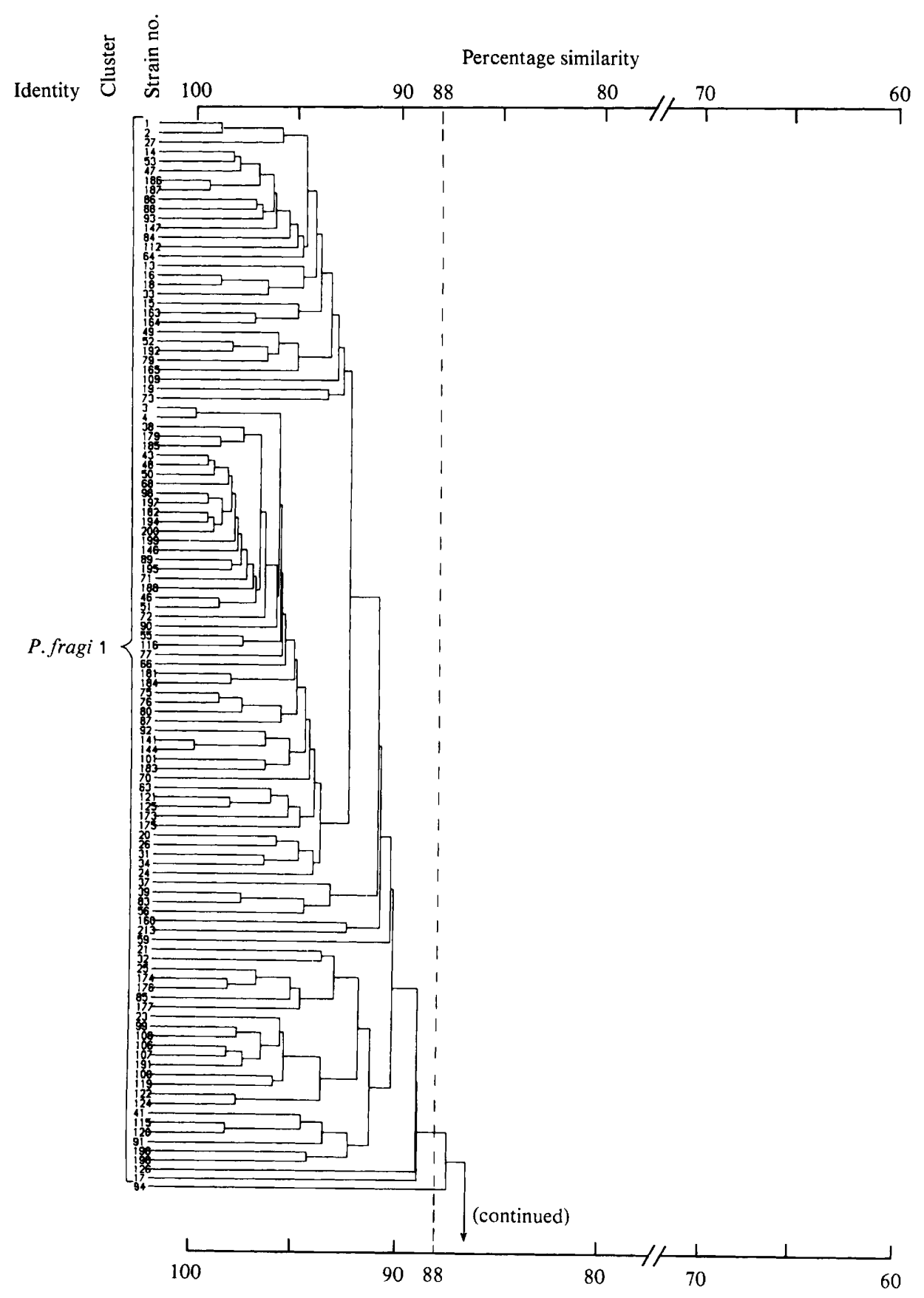

Fig. 1. Dendrogram of 218 pseudomonad strains (oxidase-positive; Gram-negative; motile by polar flagellation) showing the relationship between clusters based on the $S_{M}$ coefficient and unweighted group average linkage clustering. 


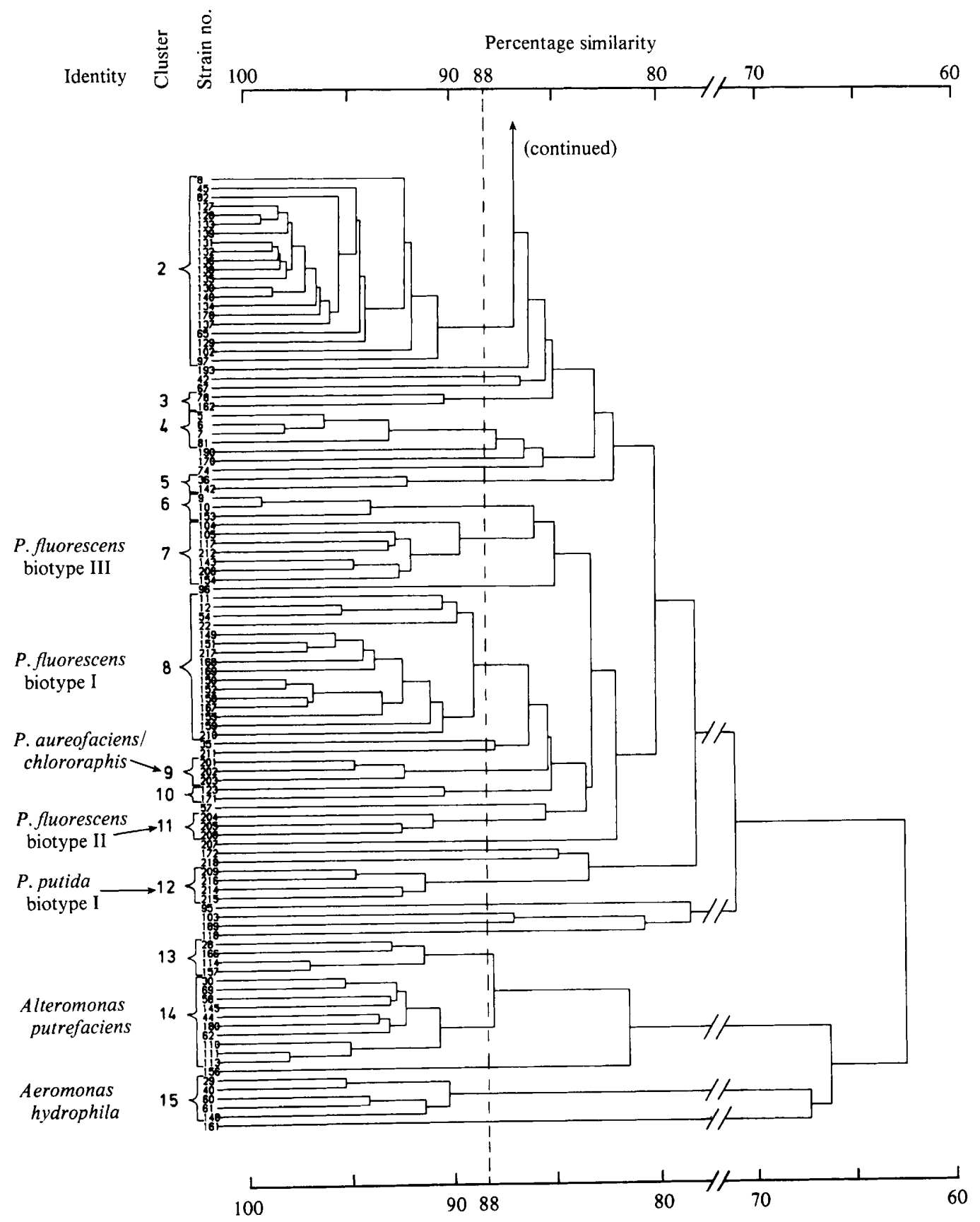

Fig. 1 (continued) 
chlororaphis and $P$. aureofaciens, respectively. The differentiation of the last two from $P$. fluorescens is based mainly on their production of phenazine pigments. However, the recognition of these organisms as separate species is not supported by the nutritional data of the present study, where $P$. aureofaciens and $P$. chlororaphis join the $P$. fluorescens complex on the same similarity level as the biotypes. In consequence, $P$. aureofaciens and $P$. chlororaphis, in accordance with Stanier et al. (1966), should be regarded as biotypes of $P$. fluorescens. Furthermore, no evidence was found in the present study for separating $P$. aureofaciens and $P$. chlororaphis. Our type and reference strains (two $P$. aureofaciens and one $P$. chlororaphis) joined together at a similarity level of $95 \%$. DNA homology studies by Palleroni \& Doudoroff (1972) also support the suggestion that aureofaciens and chlororaphis are two names for the same organism. The numerical analysis (Fig. 1) showed that $P$. fluorescens biotype I was the clustering centre for the 38 strains of the $P$. fluorescens complex. Thus, biotype I can here be regarded as the most 'typical' $P$. fluorescens group, which is in agreement with Stanier et al. (1966).

Cluster 14, Alteromonas putrefaciens, consisted of 10 field strains. Here it should be pointed out that the clustering is somewhat uncertain as it is based mainly on negative matches. Alteromonas putrefaciens was originally found in tainted butter by Derby \& Hammer (1931) and given the name Achromobacter putrefaciens, but was later transferred to the genus Pseudomonas (Long \& Hammer, 1941). On the basis of the guanine plus cytosine content of some examined strains (44-48\%), this species has been transferred to Alteromonas (Lee et al., 1977). However, three of the pseudomonads isolated were able to produce $\mathrm{H}_{2} \mathrm{~S}$ and had at the same time a guanine plus cytosine content of more than $55 \%$. Furthermore, studies on the lipid composition of $A$. putrefaciens do not support the proposal that the organism should be an Alteromonas (Wilkinson \& Caudwell, 1980). Since A. putrefaciens is the only acknowledged name (Anon., 1981) this name has been used in the present study.

In conclusion, it can be said that the principle of Stanier et al. (1966) to differentiate Pseudomonas species by testing their ability to utilize different compounds as sole carbon source seems functional. The capacity to utilize different sources for growth decreases in the order $P$. putida $<P$. fluorescens $<P$. fragi $<$ cluster $2<A$. putrefaciens. However, the diagnostic principles of Stanier et al. (1966) call for a rather large number of utilization tests, which may be inconvenient for studies not of strictly taxonomic nature. This is probably the reason why, for example, in food microbiology, the system of Shewan et al. (1960) is widely applied. This system is based on the ability to produce fluorescent pigments and on how the organism reacts on the medium of Hugh \& Leifson (1953). If this system were applied to the present material, all strains except eight $A$. putrefaciens strains would be split between Shewan's groups I and II in accordance with the ability to produce fluorescent pigments. Thus, $P$. fluorescens, $P$. putida and about half the strains of cluster 2 would be placed in group I and $P$. fragi, while the other half of cluster 2 and two $P$. putrefaciens strains would be placed in group II. All the single strains and the strains of the insignificant clusters would also be divided between Groups I and II. A more accurate division of the present material could be accomplished by using the simplified identification scheme in Table 3.

The authors are indebted to Mr Jan-Åke Sandberg for technical assistance and to Mr Ingemar Dalstrand, Lund University Computing Centre, who carried out the cluster analysis. This study was financed entirely by the Swedish Farmers' Meat Marketing Association, which is gratefully acknowledged.

\section{REFERENCES}

ANON. (1981). Validation of the publication of new names and new combinations previously effectively published outside the IJSB. International Journal of Systematic Bacteriology 31, 215-218.
Austin, B. \& Goodfellow, M. (1979). Pseudomonas mesophilica, a new species of pink bacteria isolated from leaf surfaces. International Journal of Systematic Bacteriology 29, 373-378. 
Ballard, R. W., Doudoroff, M., Stanier, R. Y. \& MANDEL, M. (1968). Taxonomy of the aerobic pseudomonads: Pseudomonas diminuta and $P$. vesiculare. Journal of General Microbiology 53, 349-361.

Ballard, R. W., Palleroni, N. J., Doudoroff, M. \& Stanier, R. Y. (1970). Taxonomy of the aerobic pseudomonads: Pseudomonas cepacia, $P$. marginata, $P$. alliicola and $P$. caryophylli. Journal of General Microbiology 60, 199-214.

Blickstad, E., Enfors, S-O. \& Molin, G. (1981). Effect of hyperbaric carbon dioxide pressure on the microbial flora of pork stored at $4{ }^{\circ} \mathrm{C}$ or $14{ }^{\circ} \mathrm{C}$. Journal of Applied Bacteriology 50, 493-504.

Breed, R. S., Murray, E. G. D. \& Hitchens, A. P. (editors) (1948). Bergey's Manual of Determinative Bacteriology, 6th edn, pp. 100-101. Baltimore: Williams \& Wilkins.

Champion, A. B., Barrett, E. L., Palleroni, N. J., Soderberg, K. L., Kunisawa, R., Contopoulou, R., Wilson, A. C. \& Doudoroff, M. (1980). Evolution in Pseudomonas fluorescens. Journal of General Microbiology 120, 485-511.

Collins, C. H. \& Lyne, P. M. (1970). Microbiological Methods. London: Butterworths.

Davidson, C. M., Dowdell, M. J. \& BoARd, R. G. (1973). Properties of Gram-negative aerobes isolated from meats. Journal of Food Science 38, 303-305.

Davis, D. H., Stanier, R. Y., Doudoroff, M. \& MANDEL, M. (1970). Taxonomic studies on some Gram-negative polarly flagellated 'hydrogen bacteria' and related species. Archiv für Mikrobiologie 70, 1-13.

Derby, H. A. \& Hammer, B. W. (1931). Bacteriology of butter. IV. Bacteriological studies on surface taint butter. Research Bulletin, Iowa Agricultural Experimental Station no. 145, 389-416.

Doudoroff, M. \& PALleroni, N. J. (1974). Pseudomonas. In Bergey's Manual of Determinative Bacteriology, 8th edn, pp. 217-243. Edited by R. E. Buchanan \& N. E. Gibbons. Baltimore: Williams \& Wilkins.

EDwards, P. R. \& EwING, W. H. (1972). Identification of Enterobacteriaceae, 3rd edn. Minneapolis: Burgess Publishing Co.

EıchHOLZ, W. (1902). Erdbeerbacillus (Bacterium fragi). Zentralblatt für Bakteriologie, Abt. 2, 9 , 425-428.

ENFORS, S-O. \& Molin, G. (1981). The influence of temperature on the growth inhibitory effect of carbon dioxide on Pseudomonas fragi and Bacillus cereus. Canadian Journal of Microbiology 27, 15-19.

Enfors, S-O., Molin, G. \& Ternström, A. (1979). Effect of packaging under carbon dioxide, nitrogen or air on the microbial flora of pork stored at $4{ }^{\circ} \mathrm{C}$. Journal of Applied Bacteriology 47, 197-208.

Florin, S. O. (1972). Experimental studies on the formation of volatile nitrogen compounds induced by Pseudomonas fragi in a synthetic medium with amino acids as source of nitrogen. Acta Veterinaria Scandinavica 13, 403-434.

Gray, P. A. \& Stewart, D. J. (1980). Numerical taxonomy of some marine pseudomonads and alteromonads. Journal of Applied Bacteriology 49, 375-383.
Grüber, T. (1902). Pseudomonas fragariae. Eine Erdbeergeruch erzeugende Bakterie. Zentralblatt für Bakteriologie, Abt. 2, 9, 705-712.

Hugh, R. \& Leifson, E. (1953). The taxonomic significance of fermentative versus oxidative metabolism of carbohydrates by various Gram-negative bacteria. Journal of Bacteriology 66, 24-26.

Hussong, R. V., Long, H. F. \& Hammer, B. W. (1937). Classification of the organisms important in dairy products. II. Pseudomonas fragi. Research Bulletin, Iowa Agricultural Experiment Station no. 225, 117-136.

King, E. O., Ward, M. K. \& Raney, D. E. (1954). Two simple media for the demonstration of pyocyanin and fluorescin. Journal of Laboratory and Clinical Medicine 44, 301.

Kovacs, N. (1956). Identification of Pseudomonas pyocyanea by the oxidase reaction. Nature, London $178,703$.

LeE, J. V., Gibson, D. M. \& Shewan, J. M. (1977). A numerical taxonomic study of some Pseudomonaslike marine bacteria. Journal of General Microbiology 98, 439-451.

LONG, H. F. \& HAMMER, B. W. (1941). Classification of the organisms important in dairy products. III. Pseudomonas putrefaciens. Research Bulletin, Iowa Agricultural Experiment Station no. 285, 174-195.

Lysenko, O. (1961). Pseudomonas - an attempt at a general classification. Journal of General Microbiology 25, 379-408.

MayfiEld, C. I. \& InNiss, W. E. (1977). A rapid, simple method for staining bacterial flagella. Canadian Journal of Microbiology 23, 1311-1313.

MisaghI, I. \& GrogAN, R. G. (1969). Nutritional and biochemical comparisons of plant-pathogenic and saprophytic fluorescent pseudomonads. Phytopathology 59, 1436-1450.

PALleroni, N. J. (1980). Isolation and properties of a new hydrogen bacterium related to Pseudomonas saccharophila. Journal of General Microbiology $117,155-161$.

Palleroni, N. J. \& Doudoroff, M. (1972). Some properties and taxonomic subdivisions of the genus Pseudomonas. Annual Review of Phytopathology, 73-100.

Pereira, J. N. \& Morgan, M. E. (1957). Nutrition and physiology of Pseudomonas fragi. Journal of Bacteriology 74, 710-713.

Pickett, M. J. \& Greenwood, J. R. (1980). A study of the Va-1 group of pseudomonads and its relationship to Pseudomonas pickettii. Journal of General Microbiology 120, 439-446.

PopofF, M. \& Veron, M. (1976). A taxonomic study of the Aeromonas hydrophila-Aeromonas punctata group. Journal of General Microbiology 94, 11-22.

Ralston, E., Palleroni, N. J. \& Doudoroff, M. (1973). Pseudomonas pickettii, a new species of clinical origin related to Pseudomonas solanacearum. International Journal of Systematic Bacteriology 23, 15-19.

Sands, D. C., Schroth, M. N. \& Hildebrand, D. C. (1970). Taxonomy of phytopathogenic pseudomonads. Journal of Bacteriology 101, 9-23.

Shaw, B. G. \& LATTY, J. L. (1981). The taxonomy of Pseudomonadaceae responsible for low-temperature spoilage of meats. In Psychrotrophic Micro- 
organisms in Spoilage and Pathogenicity. pp. 259-268. Edited by T. A. Roberts, G. Hobbs, J. H. B. Christian \& N. Skovgaard. London: Academic Press.

Shewan, J. M., Hobrs, G. \& Hodgkiss, W. (1960). A determinative scheme for the identification of certain genera of Gram-negative bacteria, with special reference to the Pseudomonadaceae. Journal of Applied Bacteriology 23, 379-390.

SiERRA, G. (1957). A simple method for the detection of lipolytic activity of micro-organisms and some observations on the influence of the contact between cells and fatty substrates. Antonie van Leeuwenhoek 23, 15-22.

Skerman, V. B. D., MCGowan, V. \& SNEath, P. H. A. (1980). Approved lists of bacterial names. International Journal of Systematic Bacteriology 30, 225-420.
Stanier, R. Y., Palleroni, N. J. \& Doudoroff, M. (1966). The aerobic pseudomonads: a taxonomic study. Journal of General Microbiology 43, 159271.

Tarrant, P. J. V., Jenkins, N., Pearson, A. M. \& Dutson, T. R. (1973). Proteolytic enzyme preparation from Pseudomonas fragi: its action on pig muscle. Applied Microbiology 25, 996-1005.

THORNLEY, M. J. (1960). The differentiation of Pseudomonas from other Gram-negative bacteria on the basis of arginine metabolism. Journal of Applied Bacteriology 23, 37-52.

Wilkinson, S. G. \& Caudwell, P. F. (1980). Lipid composition and chemotaxonomy of Pseudomonas putrefaciens (Alteromonas putrefaciens). Journal of General Microbiology 118, 329-341. 